\title{
Comportamiento mecánico de mezclas de escoria vítrea de horno alto y metacaolín activadas alcalinamente. Estudio estadístico
}

\section{Mechanical behaviour of alkali-activated blast furnace slag-activated metakaolin blended pastes. Statistical study}

\author{
I. Higuera(*), C. Varga(**), J. G. Palomo ${ }^{(*)}$, A. Gil-Maroto(**), T. Vázquez ${ }^{(* *)}$, F. Puertas ${ }^{(* *)}$
}

Recepción/Received: 4-I-11

Aceptación/Accepted: 6-II-12

\section{RESUMEN}

El estudio y desarrollo de cementos alternativos y más eco-eficientes que el cemento Portland es un tema de gran impacto a nivel científico y tecnológico. Entre esos posibles cementos se encuentran los cementos alcalinos que son materiales conglomerantes obtenidos por la interacción química de materiales silico-aluminosos cálcicos y disoluciones fuertemente alcalinas. En el presente trabajo se estudia el comportamiento mecánico y la composición mineralógica de mezclas de escoria vítrea de horno alto y metacaolín activadas alcalinamente con disoluciones de $\mathrm{NaOH}$. El objetivo de este estudio es conocer cómo afectan parámetros tales como la relación escoria/metacaolín, la concentración de la disolución activadora y la temperatura de curado, al desarrollo resistente de las mezclas. A través del estudio estadístico realizado se ha podido establecer la influencia de cada variable y modelizar el comportamiento resistente de estos cementos alcalinos. Se concluye que la concentración del activador y la relación escoria/metacaolín son los parámetros más relevantes.

Palabras clave: cementos alcalinos, escorias de horno alto, resistencias mecánicas, diseño de experimentos, ANOVA.

\section{SUMMARY}

The study and development of alternative, more ecoefficient binders than portland cement are attracting a good deal of scientific and technological interest. Binders obtained from the chemical interaction between calcium silico-aluminous materials and highly alkaline solutions are one of several types of such possible cements. The present paper discusses the mechanical behaviour and mineralogical composition of blended pastes made from $\mathrm{NaOH}$-activated vitreous blast furnace slag and metakaolin. The aim of the study was to determine how parameters such as the slag/metakaolin ratio, activating solution concentration and curing temperature affect strength development in these binders. A statistical study was conducted to establish the impact of each variable and model strength behaviour in these alkaline cements. The conclusion drawn is that activator concentration and the slag/metakaolin ratio are both determinant parameters.

Keywords: alkaline cements, blast furnace slag, mechanical strength, experimental design, ANOVA.

\footnotetext{
(*) Universidad Politécnica de Madrid, Madrid (España).

(**) Instituto de Ciencias de la Construcción Eduardo Torroja (IETcC- CSIC), Madrid (España).
} 


\section{INTRODUCCIÓN}

El desarrollo de cementos alternativos a los cementos Portland, que se produzcan a través de procesos menos energéticos y con menor impacto medioambiental, es un tema de interés científico y técnico a nivel nacional e internacional. Unos cementos que pueden cumplir estos requerimientos de eco-eficiencia son los denominados cementos alcalinos. Estos cementos se obtienen por la mezcla íntima de materiales silico-aluminosos (de origen natural o artificial) con disoluciones fuertemente alcalinas (1). Estos nuevos cementos se caracterizan por presentar bajos calores de hidratación, elevadas prestaciones mecánicas y buena durabilidad frente a diferentes agresivos químicos (medios ácidos, sulfáticos, etc.) y no requerir en su elaboración los elevados consumos energéticos que son inherentes al proceso de fabricación de los cementos Portland (2-7).

Los materiales susceptibles de ser activados alcalinamente pueden ser muy variados, desde arcillas tratadas térmicamente (como el metacaolín) (8) a residuos o subproductos industriales como las escorias vítreas de horno alto y las cenizas volantes procedentes de centrales térmicas (9-11).

Hay trabajos en los que se ha estudiado el proceso de formación, características y propiedades de mezclas de escorias, cenizas volantes y metacaolín activados alcalinamente (12-14). Estos estudios pusieron en evidencia que los parámetros más relevantes desde el punto de vista mecánico eran la relación escoria/ceniza y la naturaleza y concentración de la disolución alcalina. También se demostró que en mezclas del $50 \%$ de escoria/50\% de ceniza activadas con una disolución de $\mathrm{NaOH} 10 \mathrm{M}$ se formaban dos productos de reacción: un gel C-A-S-H debido a la activación de la escoria y un gel N-A-S-H debido a la activación de la ceniza volante. En la bibliografía también se recogen algunos trabajos en los que se han estudiados mezclas de escorias/metacaolín activadas alcalinamente (15-19), y otros sistemas. Estos estudios también han demostrado la posibilidad de coexistencia de los geles C-A-S-H y N-A-S$\mathrm{H}$ formados como consecuencia de ambos procesos, y se ha profundizado en el comportamiento durable (carbonatación) de estos nuevos cementos. Sin embargo, aún quedan algunas incógnitas sobre cómo afectan los principales parámetros implicados en los procesos de formación de estos cementos (relación escoria/metacaolín, naturaleza y concentración del activador, temperatura de curado, etc.) al desarrollo resistente de estas mezclas.

Es por ello que el presente estudio se centra en la aplicación de herramientas estadísticas para evaluar el efecto de los diferentes parámetros mencionados en las propiedades mecánicas de mezclas de escoria vítrea de horno alto y metacaolín activadas alcalinamente con disoluciones de $\mathrm{NaOH}$.

\section{INTRODUCTION}

The development of alternative, less energy-intensive binders with a lower environmental impact than Portland cements is a subject of topical scientific and technical interest, both nationally and internationally. So-called alkaline cements are among the materials able to meet eco-efficiency criteria. Such cements are obtained by mixing natural or artificial silico-aluminous materials with highly alkaline solutions (1). Alkaline cements and concretes are characterised by low heat of hydration, high mechanical strength, high resistance to aggressive chemicals (such as acids or sulfates) and preparation that consumes less energy than Portland cement manufacture (2-7).

A wide variety of materials can be alkali-activated, from thermally treated clays (such as metakaolin) (8) to industrial by-products or waste such as vitreous blast furnace slag or fly ash from coal-fired power plants (9-11).

According to the studies published on the formation, characteristics and properties of alkali-activated slag, fly ash and metakaolin blends (12-14), the parameters with the greatest impact on binder strength are the slag/ash ratio and the nature and concentration of the alkaline solution. These studies have also shown that two reaction products form when $50 \%$ slag/50\% fly ash blends are activated with $10 \mathrm{M} \mathrm{NaOH}$, namely a C-A-S-H gel resulting from slag activation and a $N-A-S-H$ gel attribu Table to fly ash activation. Reports of research on alkali-activated slag/metakaolin blends (15-19), and other systems can also be found in the literature. In addition, that research has proved that the $C-A-S-H$ and $N-A-S-H$ gels formed in these two processes can co-exist and has studied the durability (carbonation) of these new cements in depth. Nonetheless, certain gaps remain in the understanding of the manner that the main parameters involved in cement formation (such as the slag/metakaolin ratio, nature and concentration of the activator, and curing temperature) affect strength development in these pastes.

The present study therefore focuses on the use of statistical tools to evaluate the impact of the aforementioned parameters on the mechanical properties of $\mathrm{NaOH}$-activated vitreous blast furnace slag-metakaolin pastes. 


\section{EXPERIMENTAL}

\subsection{Materiales}

Para este trabajo se emplearon una escoria granulada de horno alto de origen español (BSF) y un metacaolín (MK) obtenido previamente tras la calcinación de un caolín a $750{ }^{\circ} \mathrm{C}$ durante 2 horas. La composición química de estos materiales se muestra en la Tabla 1.

\section{EXPERIMENTAL}

\subsection{Materials}

Granulated blast furnace slag (BFS) of Spanish origin and metakaolin (MK) obtained by burning kaolin at $750^{\circ} \mathrm{C}$ for 2 hours were used in this study. The chemical composition of these two materials is given in Table 1.

Tabla 1 / Table 1

Composición química de los materiales empleados.

Chemical composition of the experimental materials.

\begin{tabular}{|c|c|c|c|c|c|c|c|c|c|c|c|c|c|}
\hline & $\mathrm{SiO}_{2}$ & $\mathrm{Al}_{2} \mathrm{O}_{3}$ & $\mathrm{Fe}_{2} \mathrm{O}_{3}$ & $\mathrm{MgO}$ & $\mathrm{CaO}$ & $\mathrm{Na}_{2} \mathrm{O}$ & $\mathrm{K}_{2} \mathrm{O}$ & $\mathrm{TiO}_{2}$ & $\mathrm{P}_{2} \mathrm{O}_{5}$ & $\mathrm{SO}_{3}{ }^{-}$ & $\mathrm{S}_{2}^{-}$ & L.O.I. & I.R. \\
\hline B.F.S. & 35.3 & 13.7 & 0.4 & 4.1 & 41.0 & 0.01 & - & - & - & 0.06 & 1.9 & 2.7 & 0.6 \\
\hline M.K & 53.4 & 43.61 & 0.6 & 0.1 & 0.7 & - & 0.6 & 0.2 & 0.07 & 0.06 & - & - & - \\
\hline
\end{tabular}

L.O.I.: Pérdida al fuego; I.R.: Residuo Insoluble. / L.O.I.: loss on ignition; I.R.: insoluble residue.

\subsection{Mezclas preparadas y ensayos realizados}

Para la consecución del objetivo propuesto, se realizaron diseños factoriales $2^{2} \times 5^{1}$, en los que las variables dependientes fueron las resistencias a compresión y a flexión.

Los factores del diseño fueron: la relación escoria/metacaolín (BSF/MK) (Factor A, 5 niveles), la concentración de la disolución activadora (Factor B, 2 niveles) y la temperatura de curado (Factor $\mathrm{C}, 2$ niveles).

Se empleó como disolución activante una disolución de $\mathrm{NaOH}$ con dos concentraciones: 2 y $10 \mathrm{M}$. Se consideró apta la relación líquido/sólido (L/S) con la que se obtuvo un escurrimiento de $70 \pm 5 \mathrm{~cm}$. Es por ello que las relaciones L/S difieren en las diferentes mezclas (véase la Tabla 2), aunque su plasticidad era la misma.

Previo a su mezclado con la disolución activadora, la escoria y el metacaolín se homogenizaron con un agitador durante 4 horas. Después se prepararon probetas de pastas de cemento de $1 \times 1 \times 6 \mathrm{~cm}$, de acuerdo a la norma EN 196-1.

\subsection{Pastes prepared and trials conducted}

In the $2^{2} \times 5^{1}$ factorial designs devised for the aim proposed, the dependent variables were compressive and bending strength.

The design factors were: the slag/metakaolin (BFS/MK) ratio (Factor $A, 5$ levels), activating solution concentration (Factor B, 2 levels) and curing temperature (Factor $C$, 2 levels).

The two concentrations of the $\mathrm{NaOH}$ used as the activator were 2 and 10M. The suitable liquid/solid (L/S) ratio was defined in terms of a $70 \pm 5 \mathrm{~cm}$ slump. Hence, while the $L / S$ ratios differed from one paste to another, their plasticity was the same (see Table 2).

Prior to mixing with the activating solution, the slag and metakaolin were blended with a stirrer for 4 hours. After mixing, the cement pastes were moulded into $1 \mathrm{x}$ $1 \times 6 \mathrm{~cm}$ specimens as described in European standard EN 196-1.

Tabla 2 / Table 2

Condiciones y mezclas BSF/MK preparadas. BFS/MK paste characteristics.

\begin{tabular}{|c|c|c|c|}
\hline Mezcla / Blend & Disolución / Solution & $\mathrm{T}^{\mathrm{a}}$ Curado / Curing $T^{\mathrm{a}}$ & Relación L/S / L/S ratio \\
\hline $100 \%$ BFS & $2 M$ & $22 \pm 2^{\circ} \mathrm{C} / 85 \pm 2^{\circ} \mathrm{C}$ & 0.35 \\
\hline $100 \%$ BFS & $10 \mathrm{M}$ & $22 \pm 2^{\circ} \mathrm{C} / 85 \pm 2^{\circ} \mathrm{C}$ & 0.40 \\
\hline $70 \% \mathrm{BFS}+30 \% \mathrm{MK}$ & $2 M$ & $22 \pm 2^{\circ} \mathrm{C} / 85 \pm 2^{\circ} \mathrm{C}$ & 0.49 \\
\hline $70 \% \mathrm{BFS}+30 \% \mathrm{MK}$ & $10 M$ & $22 \pm 2^{\circ} \mathrm{C} / 85 \pm 2^{\circ} \mathrm{C}$ & 0.54 \\
\hline $50 \%$ BFS + 50\% MK & $2 \mathrm{M}$ & $22 \pm 2^{\circ} \mathrm{C} / 85 \pm 2^{\circ} \mathrm{C}$ & 0.59 \\
\hline $50 \%$ BFS + 50\% MK & $10 \mathrm{M}$ & $22 \pm 2^{\circ} \mathrm{C} / 85 \pm 2^{\circ} \mathrm{C}$ & 0.69 \\
\hline $30 \% \mathrm{BFS}+70 \% \mathrm{MK}$ & $2 M$ & $22 \pm 2^{\circ} \mathrm{C} / 85 \pm 2^{\circ} \mathrm{C}$ & 0.69 \\
\hline $30 \%$ BFS + 70\% MK & $10 \mathrm{M}$ & $22 \pm 2^{\circ} \mathrm{C} / 85 \pm 2^{\circ} \mathrm{C}$ & 0.79 \\
\hline $100 \% \mathrm{MK}$ & $2 M$ & $22 \pm 2^{\circ} \mathrm{C} / 85 \pm 2^{\circ} \mathrm{C}$ & 0.81 \\
\hline $100 \% \mathrm{MK}$ & $10 \mathrm{M}$ & $22 \pm 2^{\circ} \mathrm{C} / 85 \pm 2^{\circ} \mathrm{C}$ & 0.93 \\
\hline
\end{tabular}


Para el curado de las probetas, se emplearon dos temperaturas diferentes:

- $22 \pm 2{ }^{\circ} \mathrm{C}$ con una humedad relativa del $98 \pm 2 \%$ (cámara húmeda) durante 24 horas.

- $85^{\circ} \mathrm{C}$ durante las 2 primeras horas. Las mezclas se mantuvieron en una estufa dentro de un recipiente cerrado con agua para asegurar en todo momento un $98 \pm 2 \%$ de humedad relativa. Transcurrido este tiempo se introdujeron en la cámara húmeda durante 22 horas.

En ambos casos, transcurridas las 24 horas se desmoldaron las probetas y se mantuvieron en la cámara húmeda hasta alcanzar los tiempos de curado correspondientes (7 y 28 días). A estas edades las probetas fueron ensayadas mecánicamente a flexión y compresión.

Conviene precisar que el tiempo de curado no ha sido contemplado como un factor del diseño y que, en consecuencia, se obtienen diferentes diseños factoriales, en orden a evitar el incumplimiento de la hipótesis de independencia de los resultados, lo que invalidaría los resultados de los análisis por medio de la metodología ANOVA.

En la Tabla 2 se muestran las mezclas escoria (BFS)/metacaolín (MK) preparadas, así como las condiciones experimentales del diseño completo. En esta tabla se ofrece también la relación L/S de cada mezcla, si bien esta relación no es un factor del diseño.

El modelo asociado a este diseño sería [1]:
The specimens were cured at two temperatures:

- $22 \pm 2{ }^{\circ} \mathrm{C}$ at a relative humidity of $98 \pm 2 \%$ (humidity chamber) for 24 hours.

- $85^{\circ} \mathrm{C}$ for the first 2 hours; the pastes were placed in an oven inside a sealed flask containing water to ensure $98 \pm 2 \%$ relative humidity throughout, after which they were stored in the humidity chamber for 22 hours.

In both cases, the specimens were removed from the moulds after 24 hours and returned to the humidity chamber until the end of the curing time: 7 or 28 days. Bending and compressive strength tests were conducted at those two ages.

Curing time was not included as a design factor. Consequently, different factorial designs were obtained to prevent non-independence of results, which would invalidate ANOVA methodology.

Table 2 gives the characteristics of the slag (BFS)/metakaolin (MK) pastes, as well as the experimental conditions for the design as a whole. The Table also lists the L/S ratio for each paste, even though this was not a design factor.

The model associated with this design would be [1]:

$$
R_{i j k}=\mu+A_{i}+B_{j}+C_{k}+(A B)_{i j}+(A C)_{i k}+(B C)_{j k}+(A B C)_{i j k}+E_{i j k} \text {, }
$$

donde $\mathrm{R}_{\mathrm{ijk}}$ representa la propiedad mecánica correspondiente, resistencia a flexión o a compresión, en las condiciones experimentales ijk. $\mu$ representa la media general de la variable respuesta. $A_{i}, B_{j}$ y $C_{k}$ representan, respectivamente, las desviaciones de la media general de la variable respuesta, originados por los niveles $(i, j$, k) a que se encuentren los factores del diseño, y los términos $(A B)_{i j,}(A C)_{i k},(B C)_{j k}$ y $(A B C)_{i j k}$ representan las desviaciones respecto de la media originadas por las interacciones entre los distintos factores. Por otra parte, $E_{i j k}$ representa el error experimental.

Por último, cabe señalar que la caracterización mineralógica de las pastas se realizó a través de FTIR, para ello se utilizó un espectrómetro marca ATI Mattson, Génesis series FTIR-TM. Las muestras se prepararon por el método del comprimido de $\mathrm{KBr}$, utilizando aproximadamente $1,0 \mathrm{mg}$ de muestra problema y $300 \mathrm{mg}$ de $\mathrm{KBr}$. El barrido de frecuencias se realizó en el rango de 4.000 a $400 \mathrm{~cm}^{-1}$. where $R_{i j k}$ is bending or compressive strength under experimental conditions ijk and $\mu$ is the overall mean for the response variable. $A_{i}, B_{j}$ and $C_{k}$ are respectively the deviations from the overall mean for the response variable induced by design factor levels $i, j, k$, while the terms $(A B)_{i j,}(A C)_{i k,}(B C)_{j k}$ and $(A B C)_{i j k}$ are deviations from the mean induced by the interactions among the factors. $E_{i j k}$ in turn, is the experimental error.

Lastly, pressed $\mathrm{KBr}$ samples (approximately $1 \mathrm{mg}$ of sample per $300 \mathrm{mg}$ of $\mathrm{KBr}$ ) were mineralogically characterised on an ATI Mattson Genesis series FTIR-TM spectrometer at spanning frequencies ranging from 4000 to $400 \mathrm{~cm}^{-1}$. 


\section{RESULTADOS Y DISCUSIÓN}

\subsection{Estudio descriptivo del comportamiento mecánico de las pastas}

El análisis descriptivo del comportamiento resistente de las diferentes probetas a $22 \pm 2^{\circ} \mathrm{C}$ y $85 \pm 2{ }^{\circ} \mathrm{C}$ se muestra, respectivamente, en las Figuras 1 y 2.

El análisis y comparación de los valores resistentes de estas gráficas pone en evidencia algunos aspectos relevantes:

- El parámetro concentración de la disolución activadora parece claramente determinante a ambas temperaturas de curado, lo que se confirmará en el estudio inferencial de los diseños. Las mayores resistencias, tanto a flexión como a compresión (véanse Figuras 1 y 2), se obtienen, en términos generales, cuando la concentración de la disolución de $\mathrm{NaOH}$ es de $10 \mathrm{M}, \mathrm{y}$ hay presencia de metacaolín en las mezclas (ejemplo: $70 \%$ BSF / 30\% MK y 50\% BSF / 50\% MK). Esto está demostrando que en estas condiciones de alcalinidad se está produciendo no solo la activación de la escoria, sino también la del metacaolín.

\section{RESULTS AND DISCUSSION}

\subsection{Paste mechanical behaviour}

The variations in strength in the specimens cured at $22 \pm 2{ }^{\circ} \mathrm{C}$ and $85 \pm 2{ }^{\circ} \mathrm{C}$ are shown in Figures 1 and 2, respectively.

The analysis and comparison of these graphs led to a number of significant considerations.

- Activating solution concentration appeared to be clearly determinant at both curing temperatures, as was subsequently confirmed in the inferential study of the designs. The highest bending and compressive strength values (see Figures 1 and 2) were obtained, generally speaking, with a $10 \mathrm{M} \mathrm{NaOH}$ solution and blended pastes (i.e., 50\% BFS/50\% MK and $70 \%$ $B F S / 30 \% M K)$. This was an indication that in such a medium, both the slag and the metakaolin were activated.

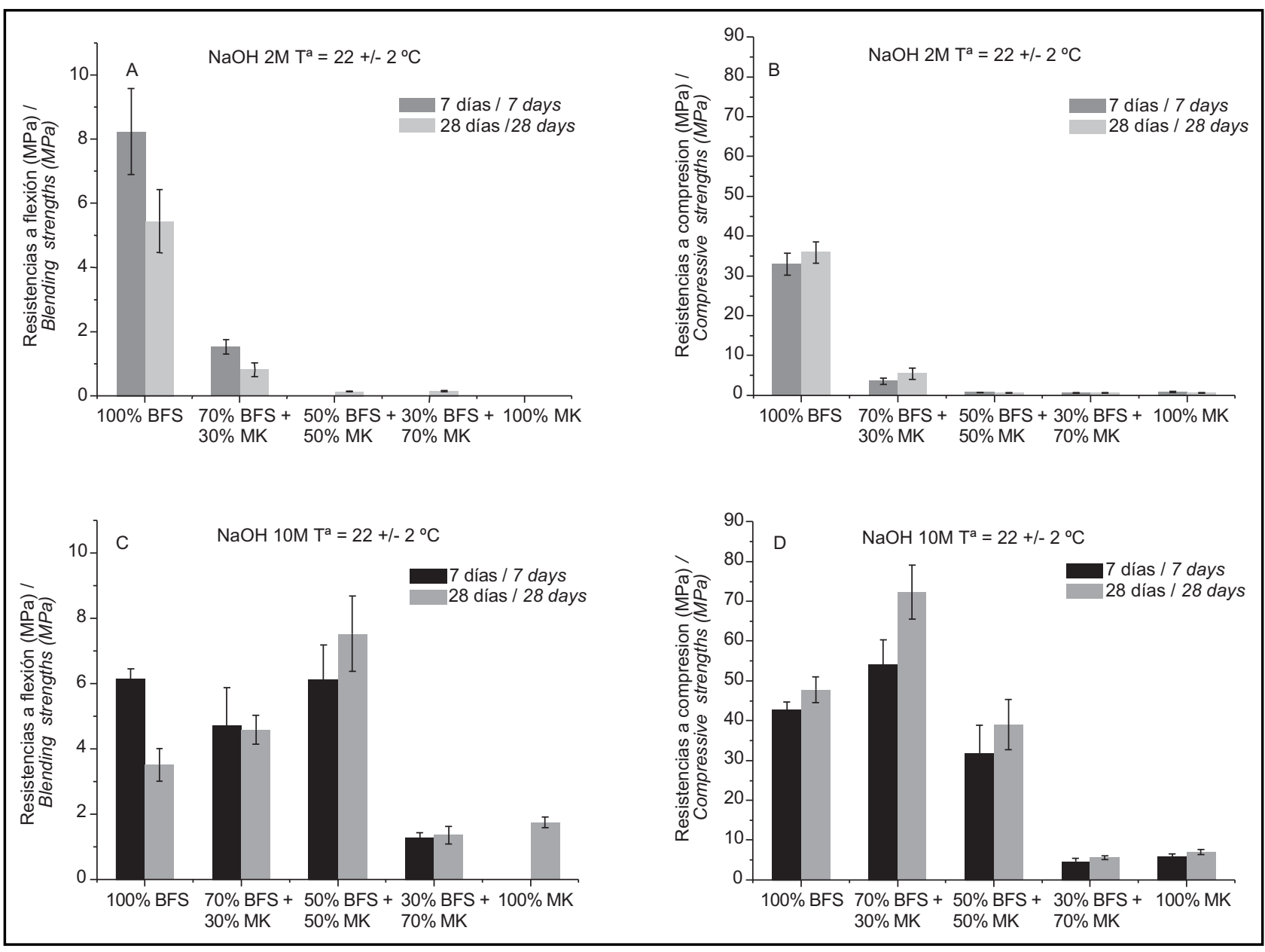

Figura 1. Evolución resistente de las pastas curadas a $22 \pm 2{ }^{\circ} \mathrm{C}$.

Figure 1. Variations in strength in pastes cured at $22 \pm 2^{\circ} \mathrm{C}$. 
- La relación BSF/MK también parece ser claramente determinante, especialmente cuando la concentración de $\mathrm{NaOH}$ es $10 \mathrm{M}$. Este hecho también será confirmado al analizar, mediante la metodología ANOVA, los resultados experimentales. Los valores mecánicos obtenidos, a ambas temperaturas de curado, muestran una acción sinérgica entre la escoria y el metacaolín; ya que los valores resistentes obtenidos muestran que en las mezclas $70 \% \mathrm{BSF} / 30 \% \mathrm{MK}$ y $50 \% \mathrm{BSF} / 50 \% \mathrm{MK}$ se promueve la activación tanto de la escoria como del metacaolín. Hay que destacar que en la mezcla $70 \%$ BSF $/ 30 \%$ MK a los 7 días de curado se obtienen resistencias a la compresión superiores a los $50 \mathrm{MPa}$, y a los 28 días se superan los $70 \mathrm{MPa}$ (valores muy superiores a los de la mezcla $100 \%$ BSF y $100 \%$ MK).

- La temperatura de curado, en este análisis descriptivo, permite intuir, como se comprobará posteriormente, que no es un factor significativo en el desarrollo resistente. Se observa que aunque se produce un incremento de las resistencias a flexión a los 7 días, a los 28 días las resistencias finales no son muy superiores, y en ocasiones incluso inferiores. A compresión se observa un ligero incremento de las resistencias,
- The BFS/MK ratio also appeared to be a determinant, particularly at $10 \mathrm{M} \mathrm{NaOH}$. This finding was likewise confirmed by the ANOVA conducted on the experimental results. The strength values obtained at both curing temperatures revealed the existence of synergies between the slag and the metakaolin, for the strength findings showed that both slag and metakaolin were activated in the $70 \% \mathrm{BFS} / 30 \% \mathrm{MK}$ and $50 \%$ BFS $/ 50 \%$ MK pastes. The 7 -day $70 \%$ BFS/30\% MK pastes exhibited compressive strength of over $50 \mathrm{MPa}$, and the 28-day samples of over 70 $\mathrm{MPa}$, compared to much lower values for the $100 \%$ BFS and $100 \%$ MK pastes.

- The strength test findings inferred that curing temperature was not a significant factor in strength development. This was also subsequently confirmed. While the 7-day bending strength values were higher at $85^{\circ} \pm 2{ }^{\circ} \mathrm{C}$ to 22 \pm 2 , 28-day strength was either not much higher or even lower. Compressive strength was observed to rise slightly at $85^{\circ} \pm 2^{\circ} \mathrm{C}$, but more

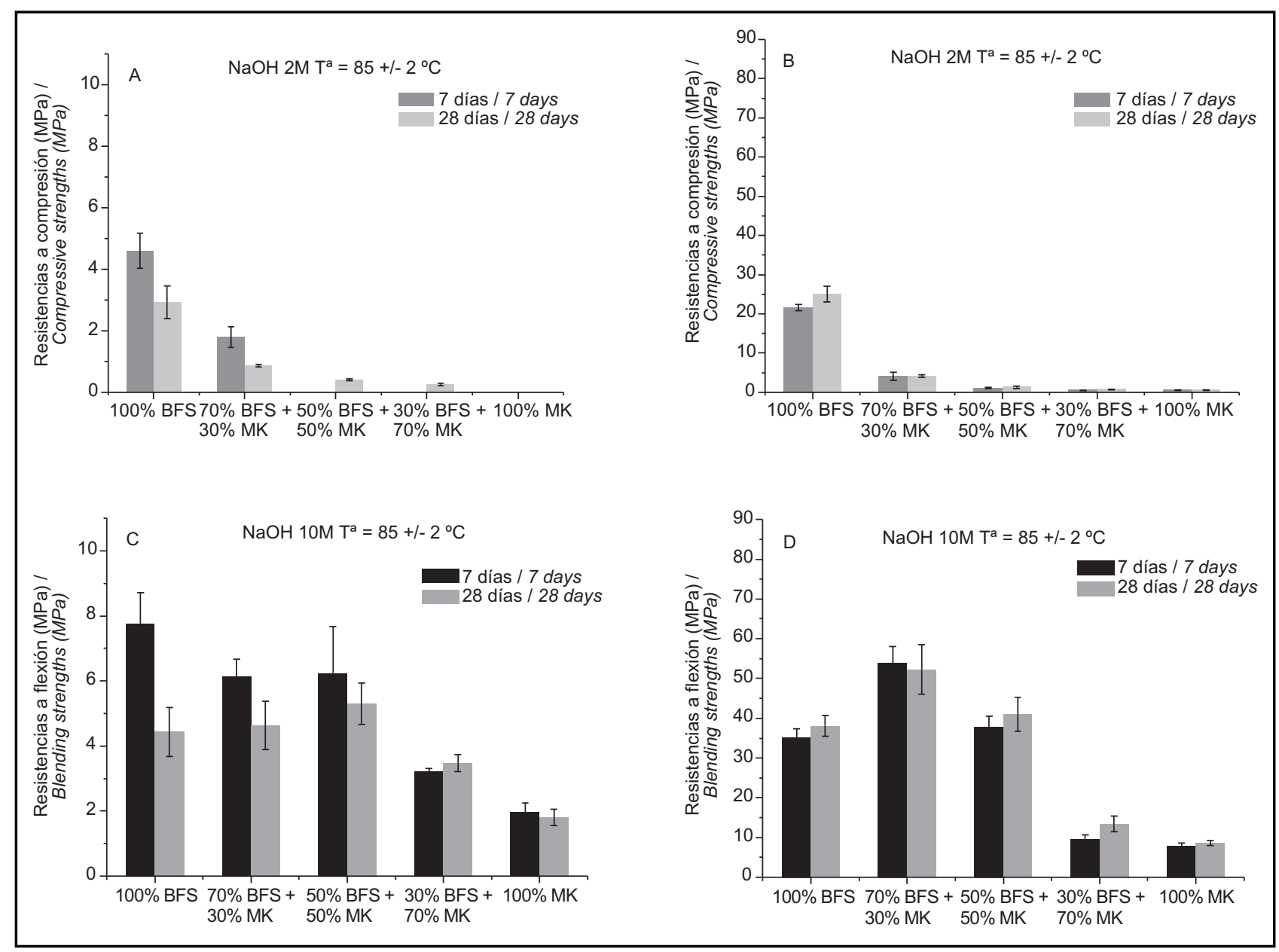

Figura 2. Evolución resistente de las pastas curadas a $85 \pm 2{ }^{\circ} \mathrm{C}$.

Figure 2. Variation in strength in pastes cured at $85 \pm 2{ }^{\circ} \mathrm{C}$. 
que parece estar más relacionado con la concentración del activador que con la temperatura de curado.

- La observación de las Figuras 1 y 2 permite conjeturar, asimismo, la existencia de una fuerte interacción entre la relación escoria/metacaolín y la concentración de la disolución, ya que la evolución de las resistencias en función de la relación escoria/metacaolín es muy distinta según los distintos niveles de la concentración de la disolución activadora. Los resultados de los análisis inferenciales, que se llevan a cabo en el apartado 3.2 confirmarán la corrección de esta conjetura.

\subsection{Análisis inferencial de los diseños factoriales realizados}

A través de la metodología ANOVA se analizaron los cuatro diseños factoriales $2^{2} \times 5^{1}$, descritos en el apartado 2.2 , en orden a discutir la existencia de diferencias significativas en el comportamiento de las variables respuesta, en función de los distintos valores de los factores y de sus interacciones.

En todos los casos se supuso nula la interacción de orden tres, con objeto de tener grados de libertad suficientes para la estimación de la varianza del error experimental.

Las Tablas 3 y 4 muestran los p-valores asociados a los contrastes de la $F$ relativos a cada factor e interacción, en los cuatro diseños realizados, así como los coeficientes de determinación, $R^{2}$, obtenidos en los mismos. En todos los casos se observa como los factores concentración del activador y composición de la mezcla son significativos al $95 \%$ (ya que sus $p$-valores son inferiores a 0,05 ), con excepción de la resistencia a la flexión a 28 días, en donde la composición de la mezcla solo es significativa al $90 \%$ $(p<0,1)$. Por otra parte, el factor temperatura de curado resulta claramente no significativo en todos los casos.

Con relación al comportamiento de las interacciones, cabe señalar que la interacción entre los factores composición de la mezcla y concentración del activador es significativa al $95 \%$ en las dos edades de la resistencia a la compresión, y al 90\%, también en las dos edades de la resistencia a la flexión.

Tabla 3 / Table 3

P-valores y coeficientes de determinación, correspondientes al análisis de los diseños factoriales relativos a la resistencia a compresión. Compressive strength $p$-values and determination coefficients for factorial design analysis.

\begin{tabular}{|c|c|c|}
\hline \multicolumn{2}{|c|}{ Resistencia a compresión / Compressive strength } \\
\hline & $\mathbf{7}$ días / 7 day p-value & $\mathbf{2 8}$ días / 28 day p-value \\
\hline Composición de la mezcla / Paste composition & $<0.00001$ \\
\hline Concentración del activador / Activator concentration & $<0.00001$ \\
\hline Temperatura / Temperature & 0.3755 & 0.002 \\
\hline Composición-concentración del activador / Composition-activator concentration & 0.0004 \\
\hline Composición-temperatura / Composition-temperature & 0.01 & 0.0587 \\
\hline R2 & 0.2741 \\
\hline
\end{tabular}

as a result of activator concentration than curing temperature.

- $A$ study of Figures 1 and 2 also suggested the existence of intense interaction between the slag/metakaolin ratio and the concentration of the solution, since the variations in strength with the slag/metakaolin ratio differed depending on the concentration of the activating solution. The inferential analysis findings discussed in item 3.2 below confirmed that interpretation.

\subsection{Inferential analysis of the factorial designs}

ANOVA analyses were conducted on the four $2^{2} \times 5^{1}$ factorial designs described in item 2.2 to ascertain the existence of significant differences in the behaviour of the response variables in terms of the factor values and their interactions.

Third order interactions were assumed to be negligible in all cases to ensure the existence of sufficient degrees of freedom to estimate the variance of experimental error.

Tables 3 and 4 show the p-values associated with the $F$-contrasts related to each factor and interaction in the four designs, as well as the determination coefficients, $R^{2}$. With the sole exception of 28-day bending strength, in which the paste composition was only significant at the $90 \%$ level $(p<0.1)$, in all other cases the activator concentration and paste composition were significant at the $95 \%$ confidence level ( $p$-value under 0.05). Moreover, curing temperature was clearly not significant in any case.

The interaction between paste composition and activator concentration was significant at the $95 \%$ level for compressive strength at both ages, and at the $90 \%$ level for bending strength, likewise at both ages. 
Tabla 4 / Table 4

P-valores y coeficientes de determinación, correspondientes al análisis de los diseños factoriales relativos a la resistencia a flexión. Bending strength $p$-values and determination coefficients for factorial design analysis.

\begin{tabular}{|c|c|c|}
\hline \multicolumn{3}{|c|}{ Resistencia a flexión / Bending strength } \\
\hline & $\mathbf{7}$ días / 7 day p-value & $\mathbf{2 8}$ días / 28 day p-value \\
\hline Composición de la mezcla / Paste composition & 0.0041 & 0.0598 \\
\hline Concentración del activador / Activator concentration & 0.0031 & 0.0056 \\
\hline Temperatura / Temperature & 0.4396 & 0.8231 \\
\hline Composición-concentración del activador / Composition-activator concentration & 0.0606 & 0.0893 \\
\hline Composición-temperatura / Composition-temperature & 0.5818 & 0.7143 \\
\hline $\mathrm{R}^{2}$ & 0.0722 & 0.5738 \\
\hline
\end{tabular}

Los gráficos de la Figura 3 presentan los comportamientos medios de la resistencia a la compresión y a la flexión a 7 días, en función de los distintos valores de la composición de la mezcla y de la concentración del activador, respectivamente, siendo similar este comportamiento en el resto de los casos.

En estos gráficos se puede apreciar cómo las resistencias, tanto a compresión como a flexión, aumentan cuando aumenta la proporción de escoria en la mezcla, y también cuando aumenta la concentración del activador.

En la Figura 4 se presenta la interacción de los factores composición de la mezcla y concentración del activador, tanto a compresión como a flexión a 7 días, respectivamente, siendo similar este comportamiento en el resto
The graphs in Figure 3 show the confidence intervals for mean 7-day compressive and bending strength for the paste composition and activator concentration values used. Similar patterns were observed for all other cases.

These graphs show that both compressive and bending strength rose with the proportion of slag in the paste and activator concentration.

The interaction between paste composition and activator concentration for 7-day bending and compressive strength is depicted in Figure 4. Similar patterns were observed for all other cases. The change in paste

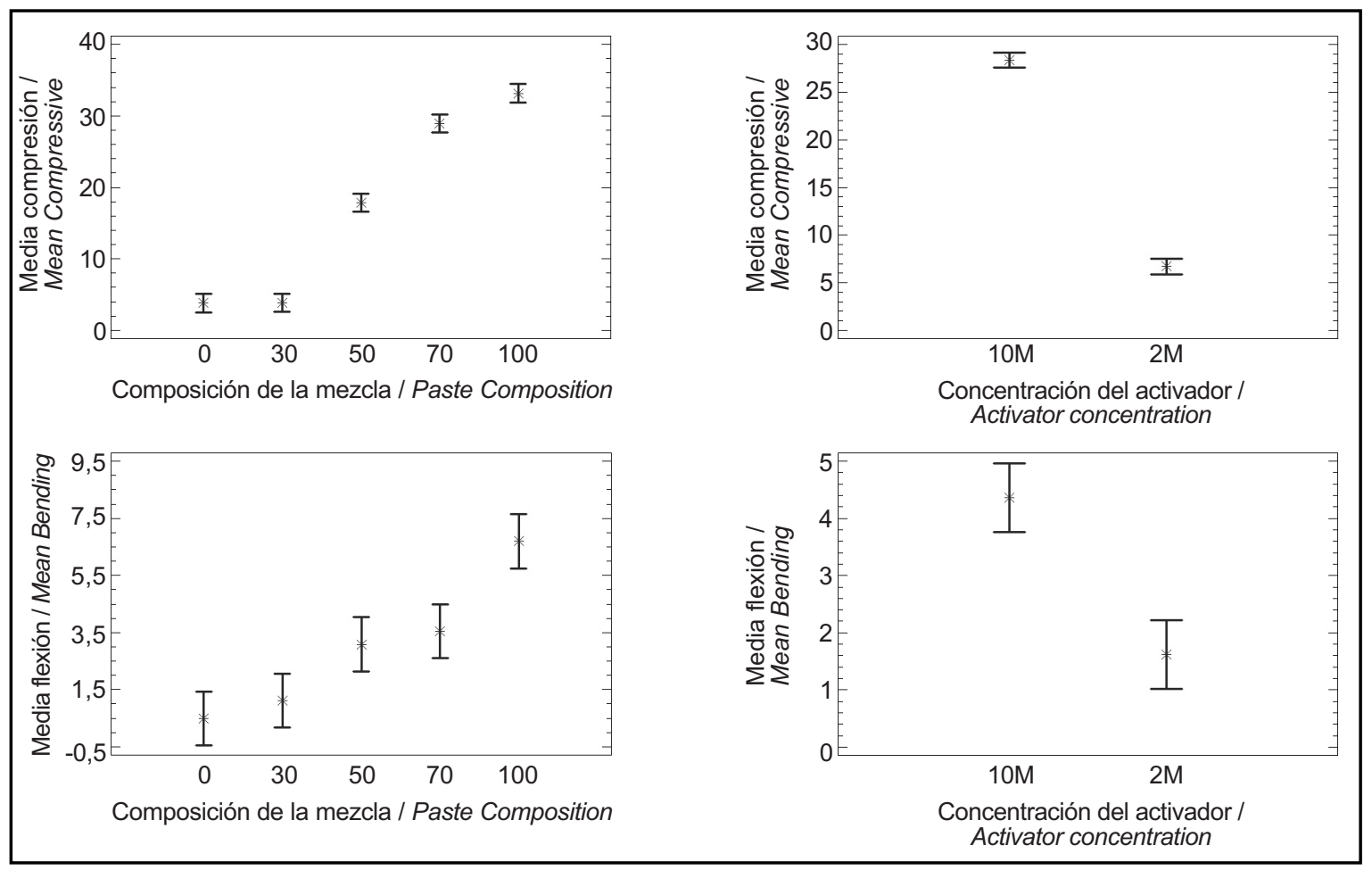

Figura 3. Intervalos de confianza para las resistencias medias a compresión y flexión a 7 días. Figure 3. Confidence intervals for mean 7-day compressive and bending strength. 


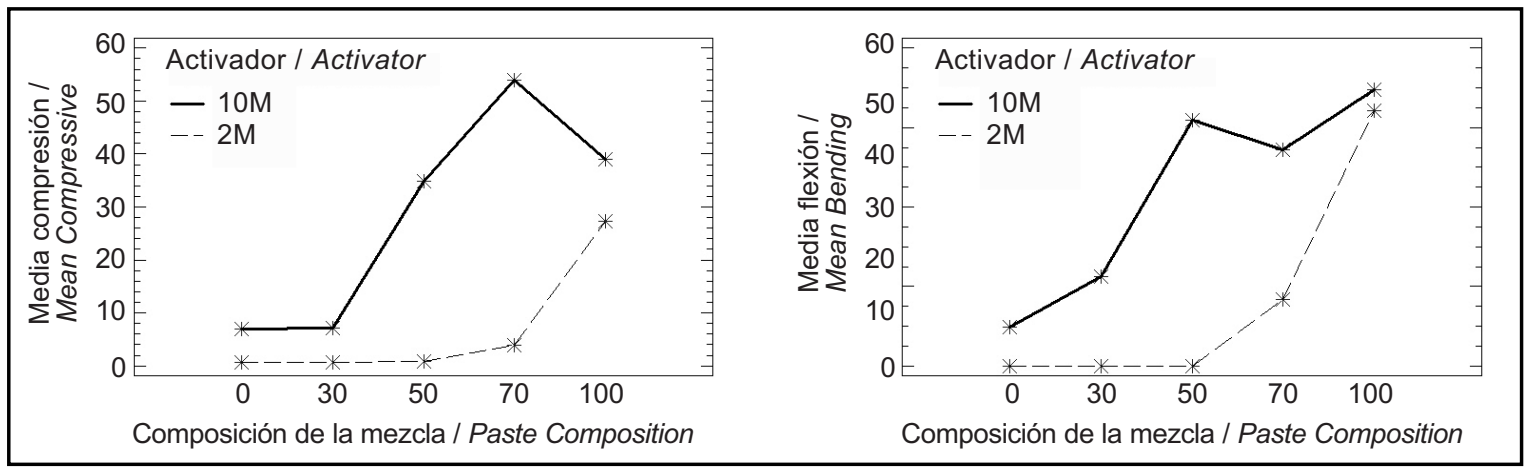

Figura 4. Interacción entre la composición de la mezcla y la concentración del activador para los valores de las resistencias a compresión y flexión a los 7 días de curado.

Figure 4. Interaction between paste composition and activator concentration in 7-day compressive and bending strength.

de los casos. En ambos casos puede observarse cómo el efecto del cambio en el nivel de la composición de la mezcla afecta de forma diferente a la variable respuesta, en función del valor de la concentración del activador.

Por otra parte, los siguientes gráficos de la Figura 5 representan las interacciones de la temperatura de curado con la composición de la mezcla y con la concentración del activador, para la resistencia a la compresión a 7 días. En los dos casos puede observarse cómo el efecto del cambio en el nivel de la composición de la mezcla, o de la concentración del activador, no parece afectar de forma muy diferente a la variable respuesta, en función del valor de la temperatura de curado. En este punto cabe llamar la atención sobre la coherencia de los resultados obtenidos en este análisis con los comentados previamente en el estudio descriptivo, así como el alto valor del coeficiente de determinación en todos los casos.

Por último, la validez de los resultados obtenidos en estos análisis depende del cumplimiento de las hipótesis básicas del modelo [1] presentado en el apartado 2.2 de este artículo. La discusión de estas hipótesis se realiza a través de los residuos del modelo. Los siguientes gráficos composition affected both response variables differently at different activator concentration values.

Similarly, the graphs in Figure 5 show the interaction between temperature and paste composition and temperature and activator concentration for 7-day compressive strength. The change in paste composition or activator concentration did not appear to affect either response variable differently at different temperatures. The results of this analysis were consistent with the experimental findings discussed earlier, and the determination coefficient exhibited a high value for both paste composition and activator concentration.

Lastly, the validity of the results of this analysis depended on the acceptability of the basic model assumptions [1] set out in item 2.2 above. The discussion of these assumptions is based on model residuals. The graphs in Figure 6, plotted on normal
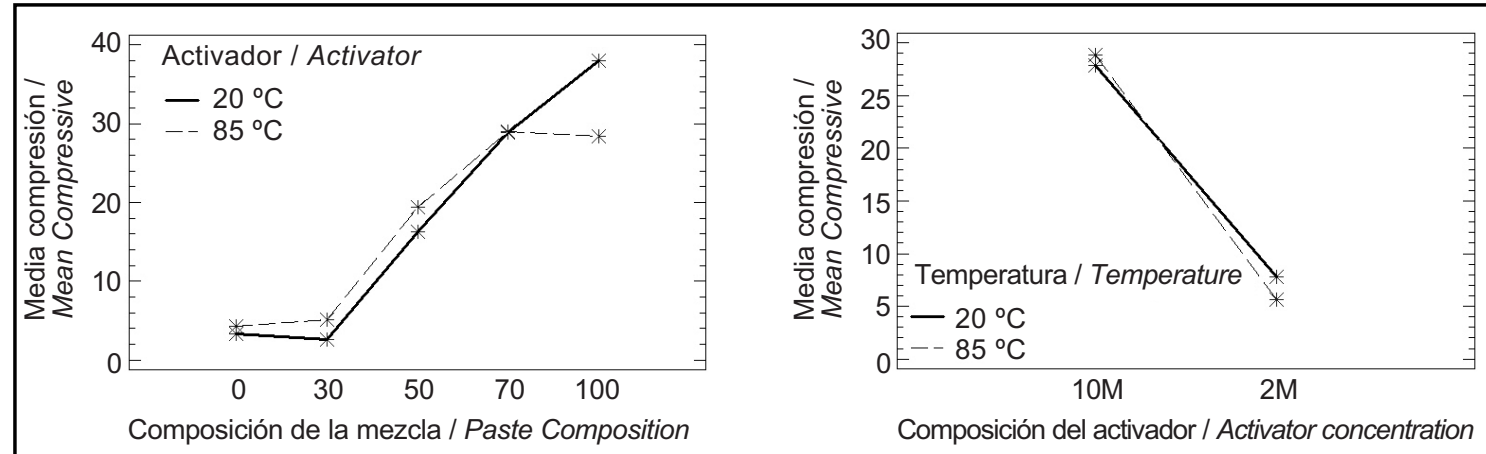

Figura 5. Interacciones de la temperatura con la composición de la mezcla y la concentración del activador para los valores de la resistencia a compresión a los 7 días de curado.

Figure 5. Interaction between temperature and paste composition and temperature and activator concentration in 7-day compressive strength. 
de la Figura 6 presentan los residuos, en papel probabilístico normal, obtenidos al ajustar los modelos para la compresión a 7 y 28 días, respectivamente. En ninguno de los dos casos se aprecian irregularidades que permitan dudar del cumplimiento de la hipótesis de normalidad del error experimental. Los gráficos obtenidos para los modelos relativos a la resistencia a la flexión permiten, también, la aceptación de la hipótesis de normalidad del error.

Sin embargo, en todos los casos, el análisis de los residuos realizado puso de manifiesto el incumplimiento de la hipótesis de homocedasticidad. Como ejemplo, puede observarse la Figura 7, en la que se representan los residuos del modelo en función de los niveles del factor composición de la mezcla, para los casos de la resistencia a la compresión a 7 y 28 días, respectivamente. Obsérvese que el rango de variación de los residuos, en el nivel 70 de la composición de la mezcla, supera claramente al triple del valor del rango de variación de los residuos en el nivel 100 de este factor.

Los análisis relativos a los modelos que se refieren a la resistencia a la flexión presentan comportamientos muy similares a estos. Por esta razón se han analizado transformaciones de los datos, no habiéndose encontrado ninguna que permitiera superar el problema de probability paper, show the model residuals for 7 and 28day compressive strength fitting. No irregularities were observed in either case that would question the acceptability of the assumption of a normally distributed experimental error. The graphs obtained for bending strength likewise confirmed acceptability of the error normality hypothesis.

By contrast, in all cases, the assumption of homoscedasticity had to be rejected on the grounds of residuals analysis. By way of example, Figure 7 plots model residuals versus the paste composition factor for 7 and 28-day compressive strength. Note that the range of variation in the residuals at paste composition level 70 clearly exceeded three times the value of the range of variation in the residuals at level 100.

The analyses for the bending strength models followed very similar patterns. For that reason, data transformations were analysed, although none was found that was able to eliminate the heteroscedasticity observed. Nonetheless, since the non-acceptability of the

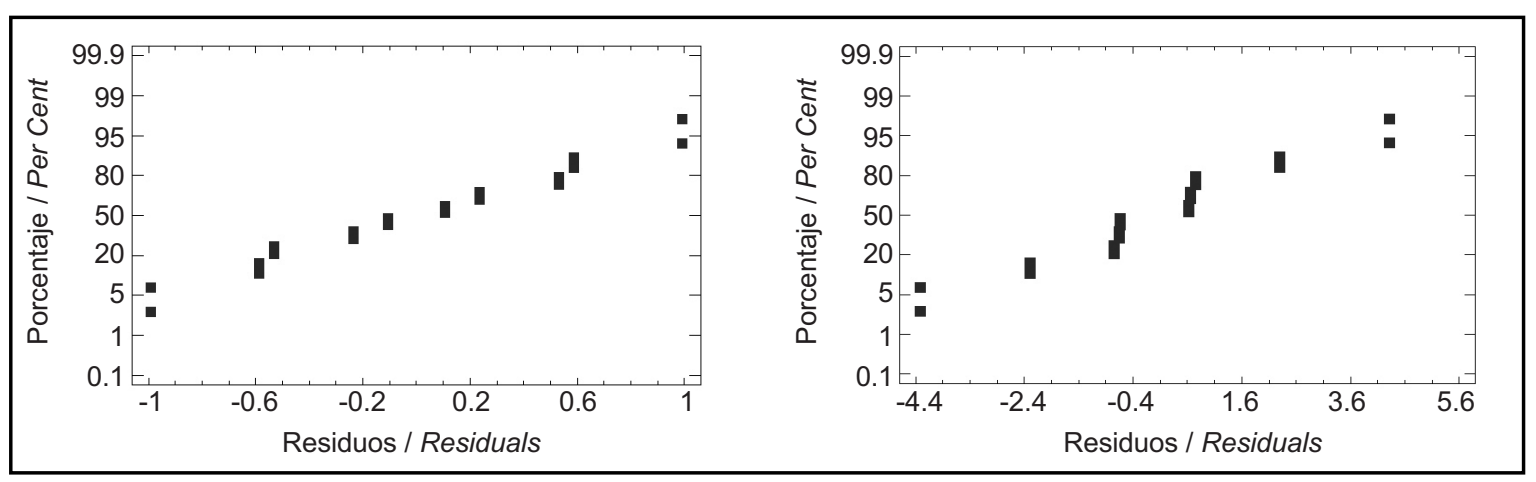

Figura 6. Residuos de los modelos para la resistencia a compresión a 7 y 28 días. Figure 6. Model residuals for 7 and 28-day compressive strength.
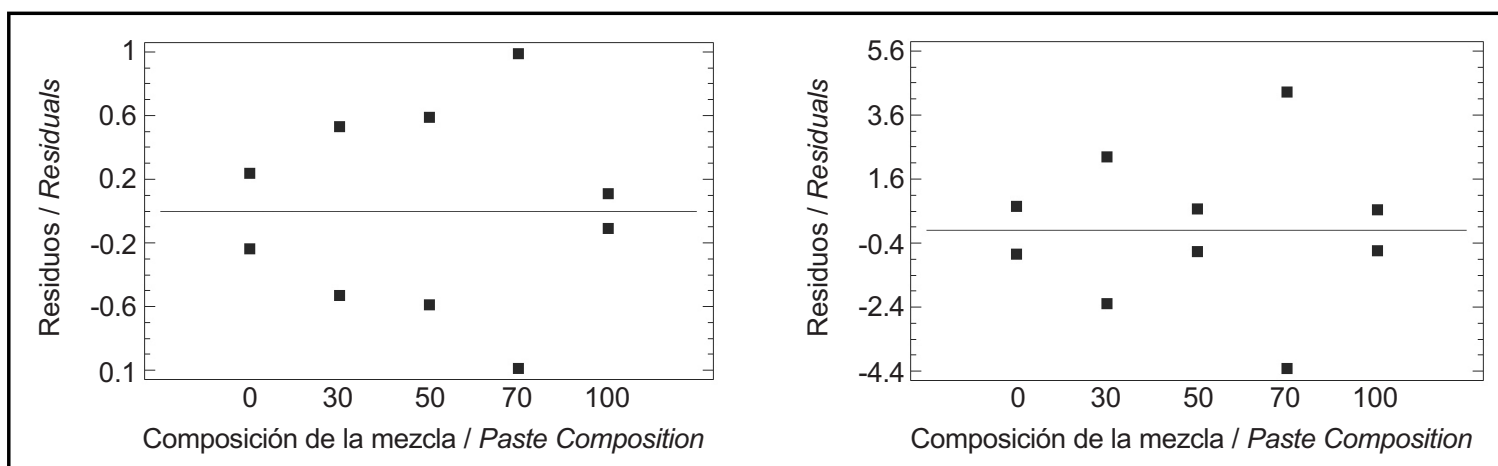

Figura 7. Residuos del modelo en función del factor composición de la mezcla. Figure 7. Model residuals vs paste composition factor. 
heterocedasticidad planteado. Ahora bien, dado que el incumplimiento de la hipótesis de homocedasticidad no afecta al test de la F, parece razonable aceptar las conclusiones halladas hasta ahora, en lo relativo a la significatividad de los distintos factores e interacciones del modelo. No obstante, si bien los estimadores de los parámetros del modelo siguen siendo insesgados y consistentes, las varianzas y covarianzas de los estimadores por Mínimos Cuadrados Ordinarios de los parámetros del modelo son sesgadas e inconsistentes, por lo que el cálculo de los intervalos de confianza de los distintos parámetros, así como los contrastes individuales relativos a los mismos, se ven gravemente afectados.

En consecuencia, dado que la heterocedasticidad de los residuos se ha presentado al comparar estos según los niveles del factor composición de la mezcla, en el siguiente apartado se procede a calcular distintos modelos en función de los valores de este factor, que permitan soslayar las dificultades encontradas. En todos estos modelos será, como en los casos anteriores, considerada nula la interacción de orden tres.

\subsubsection{Construcción de modelos no heterocedásticos}

\section{A) Resistencia a la compresión a 7 y 28 días}

Los 20 datos del diseño $2^{2} \times 5^{1}$, descrito en el apartado 2.2 de este artículo, se han separado en un diseño, D1, $2^{2} \times 3^{1}$, formado por los 12 datos en los que el factor composición de la mezcla toma los valores 0, 30 o 50\% BSF; y en un segundo diseño, D2, 23, formado por los ocho datos en los que el factor composición de la mezcla toma los valores 70 o $100 \%$ BSF.

Las Tablas 5 y 6 muestran los p-valores asociados a cada factor y a cada interacción para cada uno de los diseños factoriales D1 y D2, así como los distintos valores del coeficiente de determinación, $\mathrm{R}^{2}$, obtenidos en los mismos, respectivamente. homoscedasticity assumption did not affect the $F$ test, the conclusions drawn regarding the significance of the various model factors and interactions would appear to be reasonable. Even so, while the model parameter estimators were unbiased and consistent, the ordinary minimum square variances and co-variances of those estimators were biased and inconsistent. This impacted the calculation of confidence intervals for the parameters as well as the associated individual contrasts fairly heavily.

Consequently, since the heteroscedasticity of the residuals appeared in connection with the paste composition factor, in the following item the various models are calculated as a function of that factor to sidestep the difficulties encountered. As above, third order interactions were assumed to be negligible in all these models.

\subsubsection{Building non-heteroscedastic models}

\section{A) Seven and 28-day compressive strength}

The 20 data items in the $2^{2} \times 5^{1}$ design described in item 2.2 of this article were separated into one $2^{2} \times 3^{1}$ design, D1, consisting of 12 data items in which the paste composition factor adopted values of 0,30 or $50 \%$ BFS; and a second $2^{3}$ design, D2, comprising eight data items, in which the paste composition factor adopted values 70 or $100 \%$ BFS.

Tables 5 and 6 show the p-values for each factor and interaction under factorial designs $D 1$ and $D 2$, referred respectively to 7 and 28-day compressive strength, along with the determination coefficients, $R^{2}$.

Tabla 5 / Table 5

P-valores de los factores. Resistencias a compresión a 7 días. $P$-values for factors: 7-day compressive strength.

\begin{tabular}{|c|c|c|}
\hline \multicolumn{2}{|c|}{ Resistencia a compresión a 7 días / 7-day compressive strength } & D2 \\
\hline & D1 & 0.1611 \\
\hline Composición de la mezcla / Paste composition & 0.0032 & 0.0226 \\
\hline Concentración del activador / Activator concentration & 0.0012 & 0.1454 \\
\hline Temperatura / Temperature & 0.0542 & 0.0364 \\
\hline Composición-concentración del activado / Composition-activator concentration & 0.0033 & 0.6489 \\
\hline Composición-temperatura / Composition-temperature & 0.0562 & 0.1417 \\
\hline $\mathrm{R}^{2}$ & 0.3787 & 0.99 \\
\hline
\end{tabular}


Tabla 6 / Table 6

P-valores de los factores. Resistencias a compresión a 28 días.

$P$-values for factors: 28-day compressive strength.

\begin{tabular}{|c|c|c|}
\hline \multicolumn{2}{|c|}{ Resistencia a compresión a 28 días / 28-day compressive strength } & D2 \\
\hline & D1 & 0.8016 \\
\hline Composición de la mezcla / Paste composition & 0.01 & 0.0406 \\
\hline Concentración del activador / Activator concentration & 0.0033 & 0.4236 \\
\hline Temperatura / Temperature & 0.196 & 0.1379 \\
\hline Composición-concentración del activador / Composition-activator concentration & 0.0104 & 0.5381 \\
\hline Composición-temperatura / Composition-temperature & 0.2398 & 0.9753 \\
\hline $\mathrm{R}^{2}$ & 0.5332 & 0.71 \\
\hline
\end{tabular}

B) Resistencia a la flexión a 7 días

Asimismo, realizando una división de los datos como la de los dos casos anteriores, se obtienen los nuevos diseños D1 y D2.

La Tabla 7 muestra los p-valores asociados a cada factor y a cada interacción para cada uno de los diseños factoriales D1 y D2, así como los distintos valores del coeficiente de determinación, $\mathrm{R}^{2}$, obtenidos en los mismos.

\section{C) Resistencia a la flexión a 28 días}

En este caso, los veinte datos del diseño $2^{2} \times 5^{1}$, descrito en el epígrafe 2 de este documento, se han separado en un diseño, D1, $2^{2} \times 3^{1}$, formado por los doce datos en los que el factor composición de la mezcla, a diferencia de los casos anteriores, toma los valores 0, 30 o 70\% BSF; y por un segundo diseño, D2, $2^{3}$, formado por los ocho datos en los que el factor composición de la mezcla toma los valores 50 o $100 \%$ BSF.

La Tabla 8 muestra los p-valores asociados a cada factor y a cada interacción para cada uno de los diseños factoriales D1 y D2, así como los distintos valores del coeficiente de determinación, $\mathrm{R}^{2}$, obtenidos en los mismos.
B) Seven-day bending strength

Similarly, dividing the data as above yielded two new designs for bending strength, D1 and D2.

Table 7 gives the $p$-values associated with each factor and interaction for the two factorial designs, D1 and D2, referred to 7-day bending strength, along with the determination coefficients, $R^{2}$.

\section{C) Twenty eight-day bending strength}

In this case, the 20 data items in the $2^{2} \times 5^{1}$ design described in section 2 above were divided into a first $2^{2} \times 3^{1}$ design, D1, consisting of the 12 data items in which the paste composition factor, unlike the preceding cases, adopted the value 0,30 or $70 \%$ BFS, and a second $2^{3}$ design, D2, comprising the 8 data items in which the value of the paste composition factor was 50 or $100 \%$ BFS.

Table 8 gives the $p$-values associated with each factor and interaction for the two factorial designs, D1 and D2, referred to 28-day bending strength, along with the determination coefficients, $R^{2}$.

Tabla 7 / Table 7

P-valores de los factores. Resistencias a flexión a 7 días. $P$-values for factors: 7-day bending strength.

\begin{tabular}{|c|c|c|}
\hline \multicolumn{2}{|c|}{ Resistencia a flexión a 7 días / 7-day bending strength } & D2 \\
\hline & 0.0364 & 0.0777 \\
\hline Composición de la mezcla / Paste composition & 0.0092 & 0.1826 \\
\hline Concentración del activador / Activator concentration & 0.1571 & 0.9515 \\
\hline Temperatura / Temperature & 0.0364 & 0.3616 \\
\hline Composición-concentración del activador / Composition-activator concentration & 0.1571 & 0.3630 \\
\hline Composición-temperatura / Composition-temperature & 0.5 & 0.5318 \\
\hline $\mathrm{R}^{2}$ & 0.99 & 0.67 \\
\hline
\end{tabular}


Tabla 8 / Table 8

P-valores de los factores. Resistencias a flexión a 28 días.

$P$-values for factors: 28-day bending strength.

\begin{tabular}{|c|c|c|}
\hline \multicolumn{3}{|c|}{ Resistencia a flexión a 28 días / 28-day bending strength } \\
\hline & D1 & D2 \\
\hline Composición de la mezcla / Paste composition & 0.0249 & 0.6981 \\
\hline Concentración del activador / Activator concentration & 0.0006 & 0.1680 \\
\hline Temperatura / Temperature & 0.3929 & 0.6380 \\
\hline Composición-concentración del activador / Composition-activator concentration & 0.2356 & 0.2782 \\
\hline Composición-temperatura / Composition-temperature & 0.4042 & 0.8951 \\
\hline Concentración del activado-temperatura / Activator concentration-temperature & 0.4658 & 0.9610 \\
\hline $\mathrm{R}^{2}$ & 0.87 & 0.81 \\
\hline
\end{tabular}

D) Análisis de los diseños con datos separados

A la vista de las tablas anteriores, cabe poner de manifiesto que las conclusiones que se desprenden de los análisis de estos ocho diseños coinciden, en lo esencial con las conclusiones obtenidas al analizar los cuatro diseños completos.

El análisis de los residuos de los distintos diseños no ofrece, en esta ocasión, comportamientos anómalos, que permitan poner en duda el cumplimiento de las hipótesis básicas de los modelos, como se pone de manifiesto en los gráficos de la Figura 8, relativos a la resistencia a la compresión a 28 días. En el primero de ellos se representan los residuos del modelo frente a los niveles del factor composición de la mezcla, mientras que en el segundo se comprueba la normalidad de estos residuos a través de su representación en papel probabilístico. La comparación del primero de estos gráficos con el correspondiente de los diseños completos, Figura 7, pone de manifiesto la mejora obtenida en lo que respecta al cumplimiento de la hipótesis de homocedasticidad. La representación de los residuos en todos los demás casos se omite por no ofrecer ningún comportamiento anómalo.

\section{E) Estimación de los modelos}

Los análisis realizados permiten, como se indicó en el apartado 2.2 de este trabajo, describir el comportamiento

\section{D) Segregated data analysis}

The conclusions to be drawn from the analysis of these eight designs and from the four non-segregated designs concurred in essence.

The residuals analysis for the former, however, exhibited no anomalous behaviour that would question the acceptability of the basic model assumptions, as shown by the graphs in Figure 8 for 28-day compressive strength. The first graph depicts the model residuals by paste composition level, while the second verifies the normality of these residuals by plotting them on probability paper. A comparison of the first graph to the graph in Figure 7 for the non-segregated designs shows an improvement with respect to the homoscedasticity assumption. None of the residuals graphs for the other cases is reproduced here because they exhibited no anomalous behaviour.

\section{E) Model estimate}

As noted in item 2.2 above, the analyses conducted provided a description of strength bending and

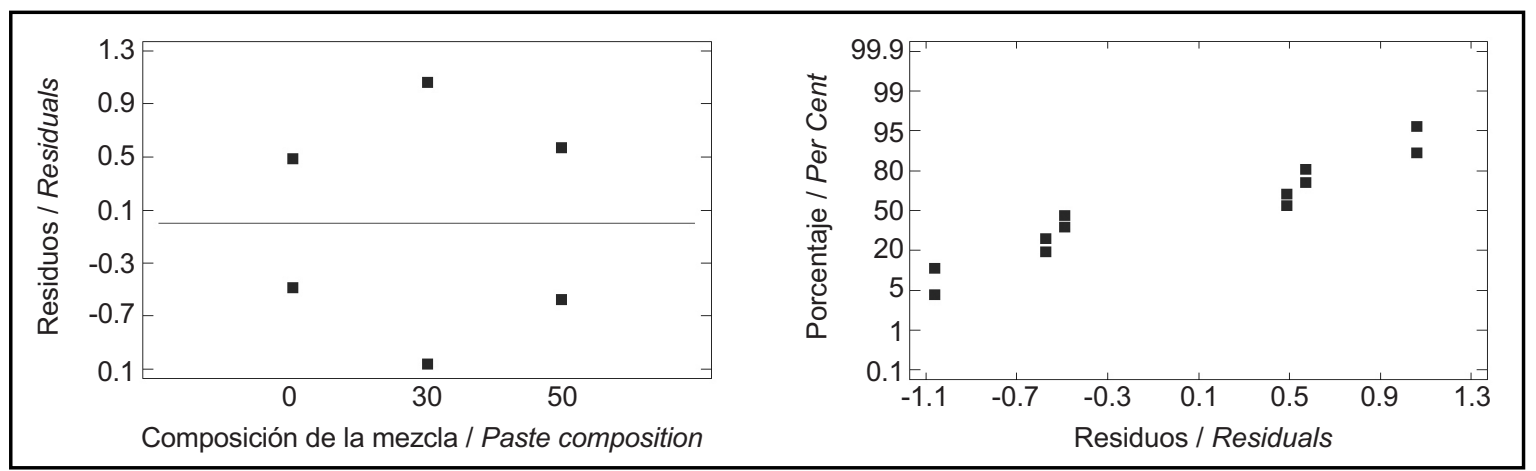

Figura 8. Análisis de los residuos.

Figure 8. Analysis of residuals. 
de las resistencias, tanto a flexión como a compresión, mediante la ecuación del modelo [1], en el que se omite la presencia de la interacción de tercer orden, por haberse supuesto nula en todos los casos:

$$
R_{i j k}=\mu+A_{i}+B_{j}+C_{k}+A B_{i j}+A C_{i k}+B C_{j k}+E_{i j k}
$$

Los siguientes esquemas contienen los coeficientes de los modelos calculados en los ocho diseños analizados, así como la desviación típica, $\sigma$ estimada por medio de la desviación típica residual correspondiente a cada uno de los modelos. Los modelos se han representado por la variable respuesta, donde RC o RF significa resistencia a la compresión o a la flexión, respectivamente, y el subíndice indica la edad a la que se estudian estas resistencias.

En el caso en que un parámetro no se encuentre en las tablas, o bien su casilla correspondiente esté en blanco, debe entenderse que su valor estimado es cero. compressive behaviour based on model equation [1], in which third order interactions were assumed to be negligible and consequently omitted.

\section{Casos D1:}

The schemes below contain the model coefficient calculated for the eight designs analysed, along with the standard deviation, $\sigma$, estimated from the residual standard deviation for each model. The models are labelled by the response variable, where $R C$ and $R F$ respectively mean compressive and bending strength while the subscript denotes specimen age.

The absence of a parameter in the tables or an empty cell means that the respective value was estimated as zero.

Designs D1:

\begin{tabular}{|c|c|c|c|c|c|c|c|c|}
\hline Modelo / Model & $\boldsymbol{\mu}$ & $\mathbf{A}_{\mathbf{0}}$ & $\mathbf{A}_{\mathbf{3 0}}$ & $\mathbf{A}_{\mathbf{5 0}}$ & $\mathbf{B}_{\mathbf{2}}$ & $\mathbf{B}_{\mathbf{1 0}}$ & $\mathbf{C}_{\mathbf{2 0}}$ & $\mathbf{C}_{\mathbf{8 5}}$ \\
\hline $\mathrm{RC}_{7}$ & 8.51 & -4.7 & -4.64 & 9.33 & -7.76 & 7.76 & -1.1 & 1.1 \\
\hline $\mathrm{RC}_{28}$ & 9.97 & -5.71 & -4.85 & 10.57 & -9.18 & 9.18 & & \\
\hline $\mathrm{RF}_{7}$ & 1.57 & -1.07 & -0.44 & 1.52 & -1.57 & 1.57 & & \\
\hline
\end{tabular}

\begin{tabular}{|c|c|c|c|c|c|c|c|c|c|c|c|c|}
\hline Modelo / Model & $\mathrm{AB}_{0,2}$ & $A B_{0,10}$ & $A B_{30,2}$ & $\mathrm{AB}_{30,10}$ & $A B_{50,2}$ & $A B_{50,10}$ & $A C_{0,20}$ & $\mathrm{AC}_{0,85}$ & $\mathrm{AC}_{30,20}$ & $\mathrm{AC}_{30,85}$ & $\mathrm{AC}_{50,20}$ & $\mathrm{AC}_{50,85}$ \\
\hline $\mathrm{RC}_{7}$ & 4.68 & -4.68 & 4.47 & -4.47 & -9.17 & 9.17 & 0.66 & -0.66 & -0.16 & 0.16 & -0.48 & 0.48 \\
\hline $\mathrm{RC}_{28}$ & 5.57 & -5.57 & 4.77 & -4.77 & -1033 & 10.33 & & & & & & \\
\hline $\mathrm{RF}_{7}$ & 1.07 & -1.07 & 0.44 & -0.44 & -1.52 & 1.52 & & & & & & \\
\hline Modelo / Model & \multicolumn{2}{|r|}{$\boldsymbol{\mu}$} & \multicolumn{2}{|r|}{$\overline{A_{0}}$} & \multicolumn{2}{|r|}{$A_{30}$} & \multicolumn{2}{|c|}{$A_{70}$} & \multicolumn{2}{|c|}{$\mathrm{B}_{2}$} & \multicolumn{2}{|c|}{$\overline{B_{10}}$} \\
\hline $\mathrm{RF}_{28}$ & \multicolumn{2}{|r|}{1.64} & \multicolumn{2}{|c|}{-0.75} & \multicolumn{2}{|c|}{-0.33} & \multicolumn{2}{|c|}{1.08} & \multicolumn{2}{|c|}{-1.29} & \multicolumn{2}{|c|}{1.29} \\
\hline
\end{tabular}

Casos D2:

Designs D2:

\begin{tabular}{|c|c|c|c|c|c|}
\hline Modelo / Model & $\mu$ & $A_{70}$ & $A_{100}$ & $\mathrm{~B}_{2}$ & $B_{10}$ \\
\hline $\mathrm{RC}_{7}$ & 31.04 & & & -15.43 & 15.43 \\
\hline $\mathrm{RC}_{28}$ & 35.16 & & & -17.49 & 17.49 \\
\hline $\mathrm{RF}_{7}$ & 5.12 & -1.57 & 1.57 & & \\
\hline Modelo / Model & $\mathrm{AB}_{70,2}$ & & & $A B_{100,2}$ & $\overline{A B_{100,10}}$ \\
\hline $\mathrm{RC}_{7}$ & $\begin{array}{l}-9.61 \\
\end{array}$ & & & 9.6 & -9.6 \\
\hline
\end{tabular}

\begin{tabular}{|c|c|}
\hline Modelo / Model & $\boldsymbol{\mu}$ \\
\hline $\mathrm{RF}_{28}$ & 3.72 \\
\hline
\end{tabular}

Desviaciones típicas de los errores experimentales:

Standard deviations for the experimental values:

\begin{tabular}{|c|c|c|}
\hline Modelo / Model & D1 & D2 \\
\hline $\mathrm{RC}_{7}$ & 0.92 & 1.55 \\
\hline $\mathrm{RC}_{28}$ & 1.84 & 16.6 \\
\hline $\mathrm{RF}_{7}$ & 0.52 & 1.88 \\
\hline $\mathrm{RF}_{28}$ & 0.75 & 2.48 \\
\hline
\end{tabular}


Puede observarse cómo, en el caso de la resistencia a flexión a 28 días para el diseño D2, ninguno de los factores resulta ser significativo, por lo que el modelo [1], definido en el punto 2.2 , se reduce a la media general.

\subsection{Resultados de FTIR}

Con el fin de conocer la naturaleza de los productos de hidratación formados $\mathrm{y}$, por tanto, explicar los valores resistentes obtenidos, se realizó un estudio por FTIR de las pastas activadas con las dos concentraciones de $\mathrm{NaOH}$ empleadas (10M y $2 \mathrm{M}$ ) a 28 días de curado, para todas las relaciones BFS/MK utilizadas. En la Figura 9 se muestran los espectros IR de todas estas pastas.

En el espectro correspondiente a la escoria anhidra (Figura 9a) aparecen a $951 \mathrm{~cm}^{-1}$ y $508 \mathrm{~cm}^{-1}$ bandas correspondientes a las vibraciones de tensión asimétrica $v_{3}$ (Si-O) y de deformación $v_{4}(\mathrm{O}-\mathrm{Si}-\mathrm{O})$, respectivamente, de los tetraedros de $\mathrm{SiO}_{4}$ y a $692 \mathrm{~cm}^{-1}$ se localiza la banda correspondiente a la vibración de tensión asimétrica de los enlaces Al-O de los grupos $\mathrm{AlO}_{4}$. La activación alcalina de la escoria, independientemente de la concentración de activador empleada, provoca un desplazamiento de la banda $v_{3}$ correspondiente a las vibraciones de tensión asimétrica hacia mayores números de onda.

La influencia de la concentración de la disolución activadora se observa claramente en todas las pastas estudiadas, pero hay que diferenciar el comportamiento de las pastas con un $100 \%$ BFS del resto. El principal producto de la activación alcalina de las escorias de horno alto es un gel C-A-S-H $(9,10,20-21)$, y su presencia en los espectros IR se manifiesta por el desplazamiento de la vibración de tensión asimétrica $v_{3}(\mathrm{Si}-\mathrm{O})$ de la escoria anhidra hacia números de onda ligeramente mayores $\left(960-995 \mathrm{~cm}^{-1}\right)$. El empleo de $\mathrm{NaOH} 10 \mathrm{M}$ como disolución activadora de la escoria produce en su espectro IR un ligero desplazamiento de $951 \mathrm{~cm}^{-1}$ a $954 \mathrm{~cm}^{-1}$ en las muestras curadas a $85^{\circ} \mathrm{C}$ y a $960 \mathrm{~cm}^{-1}$ en las curadas a $22{ }^{\circ} \mathrm{C}$ mientras que en la disolución de $\mathrm{NaOH} 2 \mathrm{M}$, este desplazamiento es mayor, alcanzando valores de $997 \mathrm{~cm}^{-1}$ con el curado a $85{ }^{\circ} \mathrm{C}$ y $970 \mathrm{~cm}^{-1}$ en las pastas curadas a $22^{\circ} \mathrm{C}$. En investigaciones previas (9) el desplazamiento observada de esa banda hacia $955-960 \mathrm{~cm}^{-1}$ indica la formación de un silicoaluminato cálcico hidratado (tipo gel C-A-S-H), y explicaría las mayores resistencias encontradas en las pastas activadas con $\mathrm{NaOH} 10 \mathrm{M}$.

En el espectro correspondiente al metacaolín anhidro (Figura 9b), las bandas asociadas a las vibraciones de tensión asimétrica $v_{3} \mathrm{~T}-\mathrm{O}(\mathrm{T}=\mathrm{Al}, \mathrm{Si})$ en este gel aparecen alrededor de $1.085-985 \mathrm{~cm}^{-1}$, y la de deformación $v_{4}(\mathrm{O}-\mathrm{Si}-\mathrm{O})$ a $460 \mathrm{~cm}^{-1}$; mientras que a $802 \mathrm{~cm}^{-1}$ aparecen los enlaces Al-O del Al tetraédricamente coordinado. Cuando el metacaolín se activa alcalinamente, la banda de tensión $v_{3}$ se desplaza a menores números de onda.
Note that for 28-day bending strength in design D2, none of the factors was significant, which simplified model [1] defined in item 2.2 to the overall mean.

\subsection{FTIR results}

An FTIR study was conducted on the 28-day (10 and 2M) $\mathrm{NaOH}$ activated pastes at all the BFS/MK ratios used, to determine the nature of the hydration products formed and therefore explain the strength values observed. The IR spectra for all the pastes are reproduced in Figure 9.

In the spectrum for the anhydrous slag (Figure 9a), the bands at $951 \mathrm{~cm}^{-1}$ and $508 \mathrm{~cm}^{-1}$ were respectively generated by tetrahedral $\mathrm{SiO}_{4} v_{3}(\mathrm{Si}-\mathrm{O})$ asymmetric stretching and $v_{4}(\mathrm{O}-\mathrm{Si}-\mathrm{O})$ bending vibrations, and the band at $692 \mathrm{~cm}^{-1}$ by Al-O bond stretching vibrations in $\mathrm{AlO}_{4}$ groups. The alkaline activation of slag, regardless of the activator concentration used, shifted the $v_{3}$ asymmetric stretching vibration band to higher wavenumbers.

The effect of activating solution concentration was readily visible in all the pastes studied, although the behaviour of the $100 \%$ BFS pastes was distinctly different from the rest. The main reaction product in the alkaline activation of blast furnace slag was a C-A-S-H gel (9, 10, 20-21), whose presence in the IR spectra was characterised by the shift of $v_{3}(\mathrm{Si}-\mathrm{O})$ asymmetric stretching vibrations in the anhydrous slag to slightly higher wavenumbers $\left(960-995 \mathrm{~cm}^{-1}\right)$. The use of $10 \mathrm{M} \mathrm{NaOH}$ as the activating solution for slag led to a slight shift on the IR spectrum from 951 to $954 \mathrm{~cm}^{-1}$ in the samples cured at $85^{\circ} \mathrm{C}$ and to $960 \mathrm{~cm}^{-1}$ in the specimens cured at $22{ }^{\circ} \mathrm{C}$. A greater shift was recorded in the $2 \mathrm{M} \mathrm{NaOH}$-activated paste: to $997 \mathrm{~cm}^{-1}$ in specimens cured at $85^{\circ} \mathrm{C}$ and to $970 \mathrm{~cm}^{-1}$ in the pastes cured at $22^{\circ} \mathrm{C}$. Prior studies (9) have shown that the shift observed in this band to around 955-960 $\mathrm{Cm}^{-1}$ was indicative of the formation of a (C-A-S-H geltype) calcium silicoaluminate hydrate, which would explain the higher strength found in pastes activated with $10 \mathrm{M} \mathrm{NaOH}$.

The spectrum for anhydrous metakaolin (Figure 9b) exhibited bands at $1085-985 \mathrm{~cm}^{-1}$ and $460 \mathrm{~cm}^{-1}$ associated with $v_{3} T-O(T=A l, S i)$ asymmetric stretching and $v_{4}(\mathrm{O}-\mathrm{Si}-\mathrm{O})$ bending vibrations, respectively, while the signal at $802 \mathrm{~cm}^{-1}$ was attributed to the Al-O bonds in tetrahedrally coordinated Al. After in metakaolin alkaline activation, $v_{3}$ absortion shift was toward lower wavenumbers. 


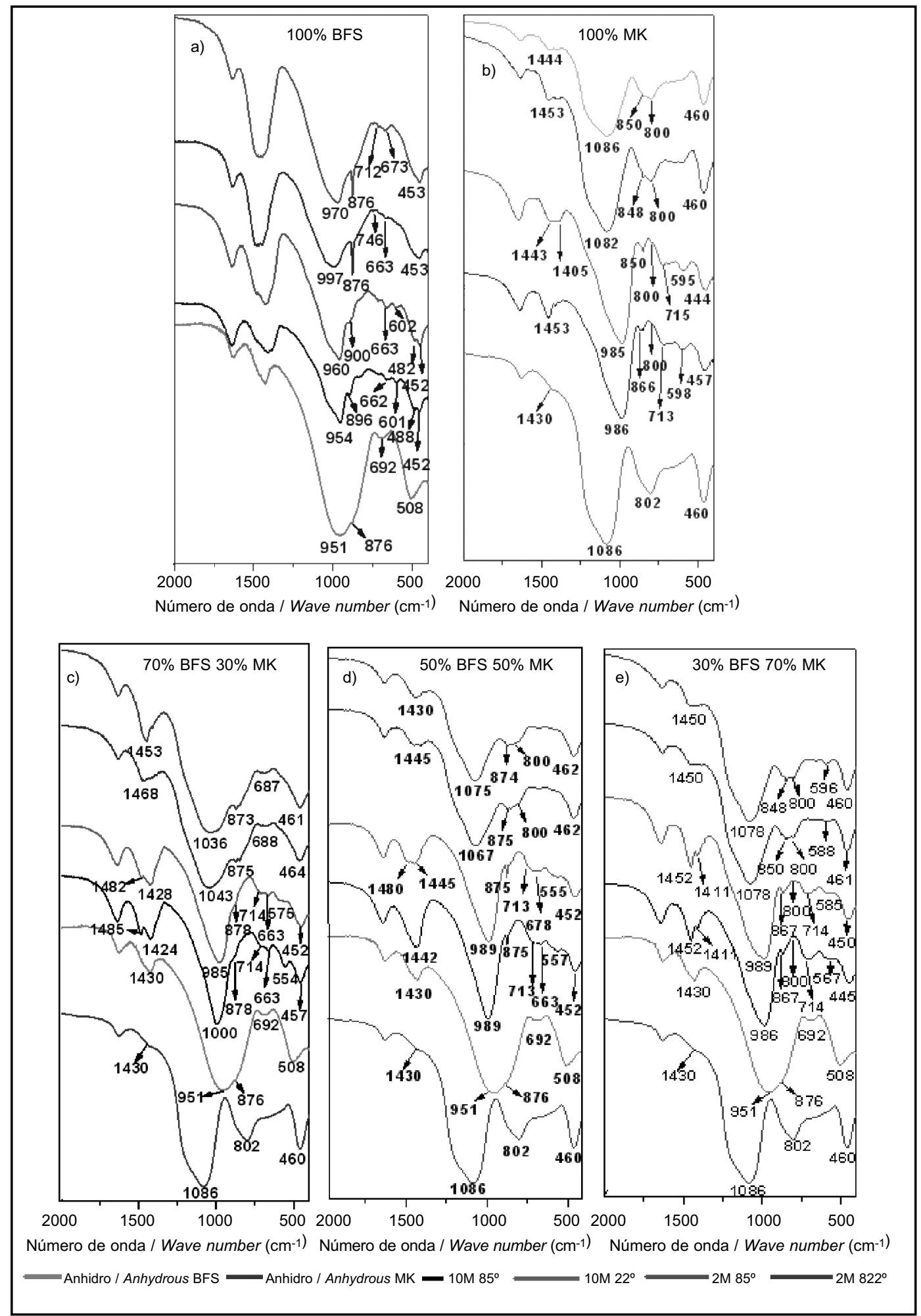

Figura 9. Espectros FTIR de las mezclas.

Figure 9. FTIR spectra for the pastes.

En los espectros de $100 \%$ MK hidratado a 28 días vemos comportamientos claramente diferenciados en función de la concentración del activador alcalino, es decir, a concentraciones bajas de activador (2M) no se producen desplazamientos en las bandas anteriormente mencionadas
The spectra for 28-day 100\% MK showed clearly distinct behaviours at different alkaline activator concentrations: at $2 M$, no shifts were observed in the aforementioned anhydrous MK bands, although slight modifications were detected due to paste carbonation (appearance of 
del MK anhidro, se observan ligeras modificaciones en los espectros debidas a la carbonatación de las pastas (aparición de absorciones alrededor de 1.450 y $850 \mathrm{~cm}^{-1}$ ), esto se ve reflejado en los resultados obtenidos en resistencias mecánicas a flexión y compresión donde no se alcanzan resistencias superiores a $1 \mathrm{MPa}$. Mientras que en estas mismas pastas (100\% MK) activadas con concentración $10 \mathrm{M}$, se observa no solo desplazamiento de la banda centrada en $1.082 \mathrm{~cm}^{-1}$ hacia menores números de onda $\left(985 \mathrm{~cm}^{-1}\right)$ sino la desaparición casi total de la banda (centrada en $802 \mathrm{~cm}^{-1}$ ) lo que indica la disolución del MK pero basándonos en la bibliografía (18) esta concentración de activador es baja para obtener la condensación total de los productos de reacción y, por lo tanto, resistencias más altas. El producto de activación alcalina del MK es un gel N-A-S-H y eventualmente zeolitas (16, 19, 22-23).

En cuanto a las pastas constituidas por mezclas de los dos materiales (BFS y MK), se observa como en todos los casos el empleo de $\mathrm{NaOH}$ en concentración $2 \mathrm{M}$ implica menores resistencias (tanto a flexión como a compresión) que en sus homólogos activados con la misma disolución pero en concentración $10 \mathrm{M}$, esto se puede relacionar con lo observado en los espectros de FTIR: En todos los casos, la banda ancha asignada a las vibraciones de tensión asimétrica de los enlaces T-O ( $\mathrm{T}=\mathrm{Al}$, Si) presenta desplazamientos de entre $1.036 \mathrm{~cm}^{-1}$ a $1.078 \mathrm{~cm}^{-1}$ esto, unido a la permanencia de la banda centrada en $800 \mathrm{~cm}^{-1}$ (Al en coordinación tetraédrica) y la banda en $460 \mathrm{~cm}^{-1}$ (deformación O-Si-O) está indicando que el MK no se está activando a estas concentraciones de activador.

Al aumentar la concentración de $\mathrm{NaOH}$ a $10 \mathrm{M}$, esa misma banda de absorción aparece desplazada hacia menores números de onda $\left(985-989 \mathrm{~cm}^{-1}\right)$, se produce a su vez el desplazamiento hacia menores números de onda de la banda de deformación de los grupos silicato y la aparición en la zona de 700-550 $\mathrm{cm}^{-1}$ bandas de tensión Al-O. Todo ello nos indica la polimerización de la estructura de un gel y, por lo tanto, el aumento en los valores resistentes obtenidos empleando como activador $\mathrm{NaOH}$ 10M. En la misma línea de lo expuesto anteriormente, la menor anchura de las bandas correspondientes a las pastas activadas con $\mathrm{NaOH} 10 \mathrm{M}$ indica un mayor orden estructural y un mayor grado de polimerización, lo que puede relacionarse, de nuevo, con los mayores valores resistentes obtenidos en estas pastas.

En cuanto a la influencia de la temperatura de curado, al igual que el caso de la medida de las resistencias mecánicas, tanto a flexión como a compresión, no se encuentran por FTIR diferencias significativas en los espectros de las diferentes pastas estudiadas. absorptions at around 1450 and $850 \mathrm{~cm}^{-1}$ ). This was reflected in the bending and compressive strength findings, where the maximum values recorded were on the order of $1 \mathrm{MPa}$. By contrast, the spectra for these same pastes $(100 \% \mathrm{MK})$, when activated with $10 \mathrm{M}$ $\mathrm{NaOH}$, exhibited not only a shift in the band centred at $1082 \mathrm{~cm}^{-1}$ to lower wavenumbers $\left(985 \mathrm{~cm}^{-1}\right)$, but the near disappearance of the signal centred at $802 \mathrm{~cm}^{-1}$, denoting MK dissolution. According to the literature (18), however, this activator concentration was too low to induce total condensation of the reaction products and consequently higher strength. The product of MK alkaline activation is a $\mathrm{N}-\mathrm{A}-\mathrm{S}-\mathrm{H}$ gel and possibly zeolites $(16,19$, 22-23).

In all the pastes consisting of blends of the two materials (BFS and MK), the use of $2 \mathrm{M} \mathrm{NaOH}$ yielded lower bending and compressive strength values than in the same materials activated with a $10 \mathrm{M}$ concentration of the activator. These observations can be related to the FTIR spectrum findings. In all cases, the wide band attributed to the asymmetric stretching vibrations induced by $T-O$ bonds ( $T=A l$, Si) shifted from 1036 to $1078 \mathrm{~cm}^{-1}$. That, together with the continued presence of the signal centred at $800 \mathrm{~cm}^{-1}$ (tetrahedrally coordinated $\mathrm{Al}$ ) and the band at $460 \mathrm{~cm}^{-1}$ (O-Si-O bending), was an indication that the $M K$ was not activated at these concentrations.

When the $\mathrm{NaOH}$ concentration was raised to $10 \mathrm{M}$, the aforementioned $v_{3}$ absorption band shifted to lower wavenumbers (985-989 $\mathrm{cm}^{-1}$ ), while the silicate group bending band also shifted to lower values and Al-O stretching bands appeared in the $700-550 \mathrm{~cm}^{-1}$ zone. All of the foregoing constituted evidence of the polymerisation of a gel structure, a finding consistent with the rise in strength values observed when $10 \mathrm{M}$ $\mathrm{NaOH}$ was used as the activator. In a similar vein, the narrowing of the bands in the pastes activated with $10 \mathrm{M} \mathrm{NaOH}$ denoted higher structural order and polymerisation. This observation can also be related to the higher strength values found for these pastes.

Curing temperature, in turn, as in the bending and compressive strength measurements, was found to induce no significant differences in the FTIR spectra for the pastes studied. 


\section{CONCLUSIONES}

Del estudio realizado se pueden extraer las siguientes conclusiones:

- La concentración de la disolución activadora es un factor claramente determinante en el comportamiento resistente de las mezclas BSF/MK, a ambas temperaturas de curado.

- La relación BSF/MK también es claramente determinante, especialmente cuando la concentración de $\mathrm{NaOH}$ es 10M. Los resultados mecánicos obtenidos, a ambas temperaturas de curado, muestran una acción sinérgica entre la escoria y el metacaolín.

- La temperatura de curado no es un factor significativo en el desarrollo resistente, aunque esta afirmación debe realizarse con prudencia, habida cuenta la alta variabilidad de los datos que podría ocultar el efecto de este factor. Por otra parte, el análisis estadístico ha demostrado que si bien no tiene por sí solo un efecto significativo en el comportamiento mecánico, sí puede modificar, a través de las interacciones, el efecto de los factores más relevantes sobre la resistencia a la flexión y compresión.

- El estudio realizado por FTIR confirma la formación de geles tipo C-A-S-H como resultados de la activación de la escoria, y tipo N-A-S-H formados por la activación del metacaolín. Al aumentar la concentración de la disolución activadora (10M) se favorece la disolución del metacaolín y la formación de fases $\mathrm{N}$ A-S-H, lo que explica el incremento de resistencias de las pastas preparadas con esta concentración de $\mathrm{NaOH}$.

- El estudio estadístico realizado ha confirmado la relevancia del parámetro composición de la mezcla y concentración del activador, mientras que deja en duda la relevancia del factor la temperatura de curado, ya que la significación de este factor podría estar oculta por la gran variabilidad de los datos, como demuestra el hecho de la gran disminución del p-valor de este factor en todos los análisis cuando se han considerado análisis separados.

- Se han propuesto los modelos matemáticos que explican el comportamiento resistente de las mezclas preparadas en este estudio.

\section{AGRADECIMIENTOS}

Los autores agradecen al Ministerio de Ciencia e Innovación la subvención otorgada a los proyectos BIA200761380 y BIA2010-15516. Los autores también agradecen a A. Gil y F. Gómez su ayuda en la realización de algunos ensayos.

\section{CONCLUSIONS}

The key conclusions to be drawn from the present study are listed below.

- Activator concentration was clearly a determining factor in strength development in BFS/MK pastes cured at both temperatures.

- The BFS/MK ratio was also an obvious determinant, particularly at $10 \mathrm{M} \mathrm{NaOH}$. The mechanical strength findings revealed synergies between the slag and the metakaolin at both curing temperatures.

- Curing temperature had no significant effect on strength development, although this observation must be viewed with caution, given the high variability of the data, which may have concealed the effect of this factor. Moreover, statistical analysis showed that while temperature had no significant impact on mechanical performance in itself, its interactions could have modified the effect of the most influential factors on bending and compressive strength.

- The FTIR study confirmed the formation of $C-A-S-H-$ type gels in slag activation, and $\mathrm{N}-\mathrm{A}-\mathrm{S}-\mathrm{H}$-type gels as the result of metakaolin activation. Raising the concentration of the activating solution (10M) favoured metakaolin dissolution and the formation of $N-A-S-H$ phases, which would explain the rise in the strength of the pastes hydrated with $\mathrm{NaOH}$ at that concentration.

- The statistical study confirmed the impact of paste composition and activator concentration, while questioning the importance of curing temperature, although the significance of this third factor may have been concealed by the high variability observed in the data, as reflected in the steep decline in the $p$ value for curing temperature in all the segregated analyses.

- Mathematical models are put forward to explain strength development in the pastes prepared in this study.

\section{ACKNOWLEDGEMENTS}

This research was funded by the Ministry of Education and Science under projects BIA2007-61380 and BIA2010-15516. The authors wish to thank A. Gil and F. Gómez for their assistance in conducting some of the trials. 


\section{BIBLIOGRAFÍA / BIBLIOGRAPHY}

(1) Puertas, F.: "Cementos de escorias activadas alcalinamente: situación actual y perspectiva de futuro", Mater. Construcc., vol. 45, no 239 (1995), pp. 53-64.

(2) Fernández-Jiménez, A.; Puertas, F.; Palomo, J. G.: Alkali-activated slag mortars: mechanical strength behaviour, Cem. Concr. Res., vol. 29 (1999), pp. 593-604.

(3) Brough, A. R.; Atkinson, A.: "Sodium silicate-based, alkali-activated slag mortars. Part I. Strength, Hydration and Microstructure", Cem. Concr. Res., vol. 32 (2002), pp 865-879. http://dx.doi.org/10.1016/S0008-8846(02)00717-2

(4) Bakharev, T.; Sanjayan, J. G.; Cheng, Y. B.: "Sulfate attack on alkali-activated slag concrete", Cem. Concr. Res., vol. 32 (2002), pp. 211-216. http://dx.doi.org/10.1016/S0008-8846(01)00659-7

(5) Bakharev, T.; Sanjayan, J. G.; Cheng, Y. B.: "Resistance of alkali-activated slag concrete to acid attack". Cem. Concr. Res., vol. 33 (2003), pp 1607-1611. http://dx.doi.org/10.1016/S0008-8846(03)00125-X

(6) Puertas, F.; Mejía de Gutiérrez, R.; Fernández-Jiménez, A.; Delvasto, S.; Maldonado, J.: "Alkaline cement mortars. Chemical resistance to sulfate and seawater attack", Mater. Construcc., vol., 52, nº 267 (2002), pp 55-71.

(7) Puertas, F.; Palacios, M.; Vázquez, T.: "Carbonation process of alkali-activated slag mortars", Journal of. Material Science, 41, 2006, pp 3071-3082. http://dx.doi.org/10.1007/s10853-005-1821-2

(8) Granizo, M. L.; Blanco, M. T.; Puertas, F.; Palomo, A.: "Alkaline activation of metakaolin; influence of synthesis parameters", Proceedings of the $10^{\text {th }}$ I.C.C.C., Goteborg, vol. 3 (2002), p. 3ii113.

(9) Puertas, F.; Fernández-Jiménez, A.; Blanco, M. T.: "Pore solution in alkali-activated slag cement pastes. Relation to the composition and structure of calcium silicate hydrate", Cem. Concr. Res., vol. 34 (2004), pp. 195-206. http://dx.doi.org/10.1016/S00088846(03)00254-0

(10) Fernández-Jiménez, A.; Palomo, A.; Sobrados, I.; Sanz, J.: "The role played by the reactive alumina contenting the alkaline activation of fly ashes", Micropor. Mesopor. Mater, vol. 91 (1-3) (2006), pp. 111-119. http://dx.doi.org/10.1016/j.micromeso.2005.11.015

(11) Sánchez, R.; Palacios, M.; Puertas, F.: "Cementos petroleros con adición de scoria de horno alto. Características y propiedades", Mater. Construcc., vol. 61, no 302 (2011), pp. 185-211. doi: 10.3989/mc.2010.54110

(12) Puertas, F.; Martínez-Ramírez, S.; Alonso, A.; Vázquez, T.: "Alkali-activated fly ash/slag cement. Strength behaviour and hydration products", Cem. Concr. Res., vol. 30 (2000), pp. 1625-1632. http://dx.doi.org/10.1016/S0008-8846(00)00298-2

(13) Puertas, F.; Fernández-Jiménez, A.: "Mineralogical and microstructural characterization of alkali-activated fly ash/slag pastes", Cem. Concr. Res., vol. 23 (2003), pp. 287-293.

(14) Chao, Li, Henghy, Sun, Longtu, Li: "A review: The comparison between alkali-activated slag (Si+Ca) and metakaolin ( $\mathrm{Si}+\mathrm{Al})$ cements", Cem. Concr. Res, vol. 40 (2010), pp. 1341-1349. http://dx.doi.org/10.1016/j.cemconres.2010.03.020

(15) Buchwald, A.; Hilbig, H.; Kaps, Ch.: "Alkali-activated metakaolin-slag blends-performance and structure in dependence of their composition", Journal of Material Science, vol. 42 (2007), pp. 3024-3032. http://dx.doi.org/10.1007/s10853-006-0525-6

(16) Bernal, S.: Carbonatación en concretos producidos a partir de sistemas binarios de una escoria siderúrgica y un metacaolín activados alcalinamente, tesis doctoral (2009), Universidad del Valle (Cali, Colombia).

(17) Buchwald, A.; Tatarin, R.; Stephan, D.: "Reaction progress of alkaline-activated metakaolin-ground granulated blast furnace slag blends", J. Mater. Sci., vol. 44 (2009), pp. 5609-5617. http://dx.doi.org/10.1007/s10853-009-3790-3

(18) Bernal, S. A.; Rodríguez, E. D.; Mejía de Gutiérrez, R.; Gordillo, M.; Provis, J. L.: "Mechanical and thermal characterization of geopolymers based on silicate-activated metakaolin/slag blends", J. Mater. Sci., vol. 46 (2011), pp. 5477-5486. http://dx.doi.org/10.1007/s10853011-5490-z

(19) Yip, C. K.; Lukey, G. C.; van Deventer, J. S. J.: "The coexistence of geopolymeric gel and calcium silicate hydrate at the early stage alkaline activation", Cem. Concr. Res., vol. 35 (2005), pp.1688-1697. http://dx.doi.org/10.1016/j.cemconres.2004.10.042

(20) Puertas, F.; Palacios, M.; Manzano, H.; Dolado, J. S.; Rico, A.; Rodríguez, J.: "Model fort he C-A-S-H gel formed in alkali-activated slag cements", Journal of European Ceramic Society, vol. 31 (2011), pp. 2043-2056. doi:10.1016/j.jeurcermsoc2011.04.036

(21) Goñi, S.; Guerrero, A.; Puertas, F.; Hernández, M. S.; Palacios, M.; Dolado, J. S.; Zhu, W.; Howind, T.: "Textural and mechanical characterization of C-S-H gels from hydration of synthetic T1- $\mathrm{C}_{3} \mathrm{~S}_{1},-\mathrm{C}_{2} \mathrm{~S}$ and their blends", Mater. Construcc., vol. 61 , no 302 (2011), pp. 169-183. doi: 10.3989/mc.2011.00511

(22) Granizo, M. L.: Activación alcalina de metacaolín: Desarrollo de nuevos materiales cementantes, tesis doctoral, Universidad Autónoma (1998).

(23) Fernández-Jiménez, A.; Palomo, A; Criado, M.: "Microstructure development of alkali-activated fly ash cement: A descriptive model", Cem. Concr. Res., vol. 35 (6) (2005), pp. 1204-1209. http://dx.doi.org/10.1016/j.cemconres.2004.08.021 